J. Product. \& Dev., 24(4): 929 - 944 (2019)

\title{
EFFECT OF SILICON LEVELS AND METHODS OF APPLICATION ON VEGETATIVE GROWTH AND FLOWERING OF ZINNIA (Zinnia elegans L.)
}

\author{
M. E. Abd El Gayed \\ Botanical Gardens Res. Depart., Hort. Res. Instit. ARC. Giza, Egypt. \\ e.mail: abdelgayedm2020@gmail.com
}

\section{ABSTRACT}

Silicon (Si) is a beneficial nutrient that improves the tolerance of biotic and abiotic stress of several crop species. Furthermore, during 2015 and 2106 seasons in a private nursery in Kafr El-Sheik Governorate, Egypt, an experimental pots research was performed to study the effects methods of application (soil or foliar application), silicon levels (0,100,200,300,400 and 500ppm) and their combinations on growth and flowering parameters, as well as the chemical composition of Zinnia elegans L. plants.

The obtained results indicated that, vegetative growth parameters (plant height, number of shoots and leaves/plant, stem thickness, leaf area and total green color (SPAD), shoot fresh and dry weights) and flowering measurements ( number of flowers/plant, flower diameter and vase life) as well as N. P. K and Si contents of leaves were significantly increased when silicon was applied as soil application as compared with foliar application method. In addition, adding silicon at either of 500 or 400ppm caused significant increases in the previous aspects.

Thus, it could be recommended to apply silicon at 500 ppm through the soil to give the best results in terms of growth, flowering and significantly prolonged flower vase life.

Key words: Silicon Levels, Vegetative, Growth, Flowering, Zinnia, Zinnia elegans L.

\section{INTRODUCTION}

Zinnia is a genus of 20 species of annual and perennial plants belonging to family Asteraceae. The genus members are popular attributed to their solitary colored flowers; therefore Zinnia elegans youn and plant is considered one of the most important ornamental plant in the world because of its successively and rapidly growing rate and also their use as cut flower (Cumo, 2013and Wahab et al., 2014). 
Silicon $(\mathrm{Si})$ is the second most abundant element in soils and its concentration in plant dry matter ranges from 1 to $10 \%$ or higher. However, it is not considered an "essential" nutrient for most plants, with the exception of some Equisitaceae members, and generally is not incorporated in commercially available fertilizers (Epstein, 1993). By 18th century, experiments around the world had shown the benefits of silicon fertilization. Nowadays, Si is considered an agronomically essential element (Ma and Takahashi, 2002). The results of initial Si experiments indicate that silicon affects gerbera plant growth and crop quality, stimulates photosynthesis, reduces transpiration rate, and enhances plant resistance to a series of both abiotic and biotic stresses such as water and chemical stresses, nutrient imbalances, metal toxicities, diseases and pests problems (McAvoy and Bible, 1996; Lu and Cao, 2001; Savvas et al., 2002). Ornamental horticulture is a field of study in which Si application could have major benefits. In floriculture, most plants are grown in containers using soilless substrates as growing media (Chen et al., 2000). Consequently, Si concentration in those media is limited and often the only source of Si provided to the plants arrives from the water supply. The application of Si to plants may improve growth, the floricultural quality of flowers and vase life (Moghaddam and Dahkaei, 2016 and Long et al., 2018).

Therefore, the objective of this study was to evaluate the effects of silicon levels and methods of application on the growth and flowering of Zinnia elegans as well as identify the best procedure for production of zinnia as a commercial pot plant.

\section{MATERIALS AND METHODS}

During the two consecutive seasons of 2015 and 2016, an experimental pot research was carried out in A Private Nursery under greenhouse conditions at Kafr El-Sheikh Governorate, Egypt to study the effect of different levels of silicon (potassium silicate $25 \% \mathrm{SiO}_{2}+10 \% \mathrm{~K}_{2} \mathrm{O}$ as a source of silicon), methods of application (soil or foliar applications) and their combinations on vegetative growth, flowering and chemical constituents of zinnia plants (Zinnia elegans L.).

Seeds were sown in polyethylene plug trays filled with a mixture of peat moss and vermiculite $(2: 1 \mathrm{v} / \mathrm{v})$ in the first week of March in both seasons. One month later, uniform seedlings of about 9-11 cm height (when 4-6 true leaves were present) were transplanted into a plastic pot $(15 \mathrm{~cm}$ diameter) filled with (clay + sand 2:1 v/v) and routinely irrigated whenever needed. The physical and chemical properties of the used soil before beginning of the experiments were determined according to Jackson (1967) and are given in Table (1). 
After one week from transplanting, one hundred and eight uniform small seedlings of Zinnia elegans were selected and arranged in a factorial randomized complete block design.

Table (1): Physical and chemical analysis of the used soil.

\begin{tabular}{|c|c|c|c|c|c|c|c|c|c|}
\hline \multirow{2}{*}{$\begin{array}{c}\mathrm{Ec} \\
\left(\mathrm{dSm}^{-1}\right)\end{array}$} & \multirow[t]{2}{*}{ O.M (\%) } & \multirow[t]{2}{*}{ pH } & \multicolumn{4}{|c|}{ Soluble cations (meq/l) } & \multicolumn{3}{|c|}{ Soluble anions (meq/l) } \\
\hline & & & $\mathrm{Ca}^{++}$ & $\mathrm{Mg}^{++}$ & $\mathbf{K}^{+}$ & $\mathrm{Na}^{+}$ & $\mathrm{So}_{4}^{--}$ & $\mathrm{HCO}_{3}^{-}$ & $\mathrm{Cl}^{-}$ \\
\hline 1.53 & 1.33 & 7.84 & 3.3 & 3.1 & 0.17 & 6.93 & 3.27 & 8.50 & 1.73 \\
\hline \multicolumn{3}{|c|}{ Particle size divisions (\%) } & Textur & \multicolumn{6}{|c|}{ Available nutrients (ppm) } \\
\hline Sand & Silt & Clay & al class & & & $\mathbf{P}$ & & $\mathbf{K}$ & \\
\hline 37.03 & 22.92 & 40.05 & $\begin{array}{c}\text { Clayey } \\
\text { Sand }\end{array}$ & & & 1.29 & & 438.40 & \\
\hline
\end{tabular}

The combinations between the two factors; the application methods (A) as a maine factor and silicon levels (B) as the sub factor in addition to their interactions resulted 10 treatments ( 2 methods of application x 6 levels of silicon ) each treatment was replicated three times with three seedlings for each replicate (3 replicates $\mathrm{x} 3$ seedlings) as follows:

I. Factor A was assigned in tow application methods as, soil or foliar applications

II. Factor B was arranged for silicon at levels of 0.0 as control, 100, 200,300,400 and 500ppm.

Spraying was performed 21 days after transplanting, once a week for three consecutive weeks till run off, while control (0) was sprayed with a distilled water only.

After three weeks from transplanting, potassium silicate $\left(25 \% \mathrm{SiO}_{2}+10 \%\right.$ $\mathrm{K}_{2} \mathrm{O}$ ) was applied weekly as drenching for three weeks.

All plants were fertilized with $4 \mathrm{~g} /$ plant calcium super phosphate $(15.5 \%$ $\mathrm{P}_{2} \mathrm{O}_{5}$ ) in one dose at the soil preparation before transplanting, $8 \mathrm{~g} / \mathrm{plant}$ ammonium sulphate $(20.5 \% \mathrm{~N})$ and $4 \mathrm{~g} /$ plant potassium sulphate $\left(48.5 \% \mathrm{~K}_{2} \mathrm{O}\right)$ for each. Nitrogen and potassium fertilizer were divided into two equal doses, the first dose was added after two weeks from transplanting and the second one was added three weeks later according to El Morsy (2011). However, all plants received the usual agricultural practices.

The following data were recorded:

1- Vegetative growth measurements:

Plant height (from main stem base to inflorescence receptacle insertion, $\mathrm{cm})$ and stem diameter $(\mathrm{mm})$ were calculated as well as number of shoots and leaves /plant, fresh and dry weight of vegetative parts a roots $(\mathrm{g}) /$ plant and 
total green color was determined on mature leaves by the SPAD - 501 (Minolta Corp, Ramsey, N.J.) according to Yadava (1986).

\section{Flowering measurements:}

Number of flowers/plant, flower diameter $(\mathrm{cm})$ as well as flower vase life (days) were determined when flowers were picked in the early morning (standard for export) and directly wrapped in groups and quickly transported to the Laboratory within 2 hours. As soon as in the Lab, stems were first precooled by placing in cold water for half an hour to remove the effect of high field heat. Thereafter, stem bases were recut under water to avoid air embolism. Stems were adjusted to the same length and shape. Healthy free stems were selected for the experiment. The longevity of zinnia cut flowers was defined by the number of days in vase life required for $50 \%$ of the flowers reach to wilting of petals.

\section{2- Nutritional status:}

Ten mature leaves/ plant (the fifth leaf from the top of the plant) were sampled in both seasons, washed, dried at $70^{\circ} \mathrm{C}$ to a constant weight, ground and digested for determination leaf minerals content. Nitrogen was determined by Micro-kjeldahl method as outlined by Chapman and Pratt (1978). Phosphorus was determined using spectrophotometer according to Murphy and Riely (1962). Potassium was determined by flame photometer according to Jackson (1967), while, leaf silicon content was determined according to Dai et al., (2005).

\section{Statistical analysis:}

Data were analyzed by MSTATC computer software program (Bricker, 1991). The obtained data were subjected to analysis of variance according Snedecor and Cochran (1990). Duncan's multiple range test (Duncan, 1955) at $5 \%$ level was used to compare the means.

\section{RESULTS AND DISCUSSION}

\section{1- Vegetative growth parameters: a- Plant height, number of shoots and leaves/plant}

Results presented in Table (2) revealed that there were no significant differences between the two applications methods of (soil or foliar applications) for plant height, No. of shoots and leaves/plant in both seasons, except for No. of Shoots and leaves/plant in the second season only as the differences were significant. The highest values in this respect recorded with zinnia plants treated with potassium silicates as soil application. Increasing 
silicon levels from 0 up to 500 ppm significantly increased growth parameters (plant height, No. of Shoots and leaves/ plant) especially, silicon at $500 \mathrm{ppm}$ which recorded the highest values in this respect. With regard to the interaction 
between application methods (soil and foliar applications) and silicon levels the results showed that the highest values of growth parameters were recorded for zinnia plants treated with silicon as soil drench at $500 \mathrm{ppm}$ for both seasons. Improving vegetative growth parameters by potassium silicate may be due to the role of potassium in ionic balance which is reflected in nitrate metabolism (Jeschke and Wolf, 1985). Also, increasing plant height may be attributed to the role of silicon in elongating and strengthening plant roots resulting in increasing the ability to take up higher amount of nutrients from the soil solution (Ma and Yamaji, 2006). These results are in agreement with those of Kamenidou (2005) on Zinnia elegans who found that, potassium silicate drench treatments (100 and $200 \mathrm{mg} / \mathrm{L} \mathrm{Si}$ ) enhanced plant height more than control. Likewise, the results of Zhao et al., (2013) on Paeonia lactiflora Pall. and Abdelkader et al., (2016) on roselle growth (Hibiscus sabdariffa L.), Abo El-Enien et al., (2017) on citrus seedlings and Magouz (2017) on Catharanthus roseus, L..

\section{b- Stem thickness, leaf area and total green color (SPAD):}

Data presented in Table (3) showed that, stem thickness and leaf area were significantly increased when zinnia plants were treated with silicon as soil application compared with foliar application in both seasons. There were not significant differences between the two application methods regarding the parameter of total green color (SPAD) for both season.

Silicon treatments caused an increase in stem thickness, leaf area and total green color compared with control. Silicon at 500ppm followed by 400 ppm produced highly significant increment during both seasons. The differences among sex levels were significant in the two seasons. As for the interaction between both factors, the highest values of previous parameters were obtained from silicon applied as soil drench at 500ppm compared with the lowest values obtained from combined treatment of application method as foliar $\mathrm{x}$ control. The increment in chlorophyll content by using silicon may be due to that $\mathrm{Si}$ application improves photosynthetic rate and enhances photochemical efficiency, also may be due to increase in grana number and the enlarge size of chloroplasts in leaves or that silicon deposition in the cell wall, gives resistance and hardness, (Epstein, 1999), resulting in opening angle of leaves and more erect leaves, and favoring photosynthesis by improving light interception (Zhiming et al., 2015). In addition, Xing and Lei (1998) showed that, the mechanism and effect of silicon fertilizer to plant may be due to that it 
could promote the formation of silicide cells and thicken cell wall after absorption of silicon fertilizer.

Therefore, it was beneficial for stems and leaves to strengthen and increase leaf photosynthesis. The obtained results show similarity to findings 
by Abdelkader et al., (2016) on roselle (Hibiscus sabdariffa L.), Magouz (2017) on Catharanthus roseus, L., and Long et al., (2018) on chive (Allium schoenoprosum L.) who found that, the application of silicon fertilizer during could improve the growth and increase chlorophyll content of plant leaves.

\section{c- Fresh and dry weight of vegetative parts and roots:}

Results presented in Table (4) showed that treatments of silicon application methods, silicon levels and their combinations significantly increased fresh and dry weights of vegetative parts and roots of Zinnia compared to the control. Soil application method showed the highest values of the pervious parameters as compared with foliar application method in both seasons. Plants treated with silicon showed higher fresh and dry weight of vegetative parts and roots compared with the control. Silicon treatment at 500 or $400 \mathrm{ppm}$ had more impact on increasing fresh and dry weights of Zinnia.

The increasing of dry matter production is often a result of $\mathrm{Si}$ supplementation, which may be due to stimulating photosynthesis, reducing transpiration rate and strengthening tissue of several plant species, especially $\mathrm{Si}$ accumulators (Ma and Takahashi, 2002). Similarly, Vendrame et al., (2010), found that, that the application of $\mathrm{KSiO}_{3}$ affects overall growth of Phalaneopsis orchid liners and increased fresh and dry weights of root, shoot and whole plant over the control plants. In the same line, Bayat et al., (2013) on pot marigold (Calendula officinalis L.) and Moghaddam and Dahkaei (2016) on Zinnia (Zinnia elegans Jacq. 'Magellan') obtained similar results.

\section{2- Flowering measurements:}

\section{a- Number of flowers/plant and flower diameter}

Data registered in Table (5) indicated that silicon treatments significantly enhanced flowering measurements. Soil-applied $\mathrm{Si}$ was increased number of flowers/plant (5.88 and 6.00) and flower diameter $(6.40$ and $6.57 \mathrm{~cm})$ compared with foliar-applied $\mathrm{Si}$ which recorded the lowest number of flowers (5.38 and $5.05)$ and diameter values $(5.74$ and $5.68 \mathrm{~cm})$ in both seasons, respectively. Silicon treatments at 500 or $400 \mathrm{ppm}$ significantly increased number of flowers and flower diameter compared with the treatment consisted of a control (no $\mathrm{Si}$ application ). The other treatments gave intermediate values in both seasons. There were a significant interactions between Si-application methods and silicon levels on the flower parameters (Table 5). Under soil- applied Si and silicon levels at 400 and 500ppm number of flower and flower diameter 
were markedly higher than control (no Si application ). These results are in harmony with those of Abou-El-Ghait et al., (2007) on Helichrysum bracteatum; Kamenidou et al., (2009) on Zinnia elegans; Kamenidou et al. (2010) on gerbera (Gerbera hybrid L.), Zhao et al., (2013) on Paeonia 
lactiflora Pall., El-Serafy (2015) on carnation (Dianthus caryophyllus L.) and Magouz (2017) who indicated that silicon significantly raised number of flowers/plant of Catharanthus roseus, L. In addition, Kamenidou (2005) found that the greatest flower diameter was obtained zinnia plants were treated with Si as compared with untreated plants. Also, Kamenidou et al., (2010) recorded that Gerbera produced thicker flower pedancles, increased flower diameter, increased height and flowered earlier when treated with silicon.

\section{b- Flower vase life (day)}

Data presented in Table (5) showed that there were no significant differences between soil and foliar applications of silicon for vase life of flowers in both seasons. The highest flower longevity was obtained with the treatment of silicon at $500 \mathrm{ppm}$ (9.5 and 10 days) followed by silicon at 400ppm (9.16 and 8.83days) with significant differences in between.

On the other hand, the control (no Si application) showed a shorter vase life (5.5 and 6.16 days), respectively in both seasons. Combining $\mathrm{Si}$ at 500ppm applied as soil drench induced highly significant increase in flower vase life when compared to other combination treatments in both seasons. Using silicon treatments prolonged the vase life of Zinnia cut flowers, which may be due to accumulating mono-silicic acid polymerizes into poly-silicic acid and then transforms to amorphous silica, which forms a thickened silicon-cellulose membrane, by this means, a double cuticular layer protects and mechanically strengthens plants (Hodson and Sangster,1988). Also, Si might form complexes with organic compounds in the cell walls of epidermal cells, therefore increasing their resistance to degrading enzymes. Silicon treatment increased superoxide dismutase activity, decreased accumulation of malondialdehyde, delayed the climacteric ethylene production and extended the vase life of carnation and gerbera flowers (Snyder et al., 2007). These results are in harmony with those of Kazemi et al., (2012) on cut lisianthus and Zaky (2013) who found that, silicon treatments significantly prolonged vase life of roses (Rosa hybrida L.) comparing with untreated plants. El-Serafy (2015) found that, $\mathrm{K}_{2} \mathrm{SiO}_{3}$ treatment significantly increased the longevity of cornation $\mathrm{cv}$. Farida cut flowers.

\section{3- Nutritional status:}

The Results presented in Table (6) revealed that, applying $\mathrm{Si}$ as soil drench significantly increased nitrogen percent in Zinnia leaves $(2.44 \%)$ than 
foliar-applied $\mathrm{Si}$ in the first season, but in the second one there were no significant differences between the two application methods (soil and foliar application). 
Regarding the silicon levels, treated zinnia plants with $\mathrm{Si}$ at $500 \mathrm{ppm}$ significantly raised nitrogen percent in the leaves as resulted 2.64 and $2.50 \%$ compared to the lowest $\mathrm{N}$ percent (1.99 and $2.01 \%$ ) occurred by control in both seasons, respectively. The combination treatment of silicon applied as soil drench with silicon level at 500ppm significantly increased leaf $\mathrm{N} \%$ as compared with the other treatments. P, K\% and Si ppm of Zinnia leaves were increased under silicon as soil drench than foliar application method. Increasing silicon levels from 0 up to 500ppm markedly raised leaf $\mathrm{P}, \mathrm{K} \%$ and $\mathrm{Si} \mathrm{ppm}$.

Regarding the interaction, there were significant differences among combination treatments in both seasons. the highest values in this respect were obtained by the combination treatment of soil-applied $\mathrm{Si}+$ high $\mathrm{Si}$ level, 500pm. These results are in harmony with those of El-Serafy (2015) on Farida carnation cut flowers, Magouz (2017) on Catharanthus roseus, L and Abo El-Enien et al., (2017) on citrus seedlings who found that, $\mathrm{K}_{2} \mathrm{SiO}_{3}$ treatment significantly increased leaf minerals as compared with control (untreated plants).

Conclusively, it can be concluded that treating Zinnia (Zinnia elegans L.) with silicon as soil drench at 500 or $400 \mathrm{ppm}$ had a positive effect on growth, flowering and increased the nutrition stats of plants and significantly prolonged flower vase life.

\section{REFERENCES}

Abdelkader, M.A.; M.A. Ibrahim and L.C. Burras (2016). Effect of silicon application on roselle (Hibiscus sabdariffa L.) grown in a Vertisol in Egypt. J. Soil Sci. Environ. Manage., 7 (4): 45-52.

Abo El-Enien, M.M.S.; B. Abo El-Kassim Aml; A.M. El-Azaze and F.S. El- Sayed (2017). Effect of silicon, potassium and calcium compounds on growth and increase the efficiency of citrus seedlings to resist citrus leafminer (Phyllocnistis citrella). J. Product. \& Dev., 22(3): 729 - 749.

Abou-El-Ghait, E.M.; G.E. Attoa; A.S. El-Khayat and E.H. Younis (2007). Effect of spraying with some calcium forms, sodium silicate and growth retardants on growth, flowering and handling of straw flower (Helichrysum bracteatum, Andr). Fayoum J. Agric. Res. \& Dev., 21 (2): 271-290.

Bayat, H.; M . Alirezaie.; H. Neamati and A. A.Saadabad (2013). Effect of silicon on growth and ornamental traits of salt-stressed Calendula (Calendula officinalis L.). Journal of Ornamental Plants, 3( 4): 207-214. 
Bricker, B. (1991). MSTATC: A Micro Computer Program from the Design Management and Analysis of Agronomic Research Experiments. Michigan State.

Chapman, H.D. and P.F. Pratt (1978). Methods of Analysis for Soils, Plant and Water. Univ. California USA.

Chen, J.; R.D. Caldwell; C.A. Robinson and R. Steinkamp (2000). Let's put silicon back to soil. Greenhouse Product News, 10(13):11-22.

Cumo, C.M.(2013). Encyclopedia of Cultivated Plants: From Acacia to Zinnia [3 volumes]: ABC-CLIO BC-CLIO, Santa Barbara, California, 1163 pp.

Dai, W.M., K.Q.Zhang; B.W. Duan; C.X.Sun; K. L. Zheng; R. Cai and J.Y. Zhuag (2005). Rapid determination of silicon content in rice .Rice Sci., 12:145-147.

Duncan, B.D. (1955). Multiple range and multiple F-test. Biometrics, 11:1-42.

El-Morsy, Noha, A. A. (2011). Use of ornamental annual plants for aesthetization of green areas. M.Sc. Thesis, Fac. Agric., Kafr El-Sheikh Univ., Egypt.

El-Serafy,R.S. (2015). Effect of silicon and calcium on productivity and flower quality of carnation. Ph. D. Thesis, Fac. Agric. Tanta Univ., Egypt.

Epstein, E. (1999). Silicon. Annual Review of Plant Physiology and Plant Molecular Biology., 50(1): 641-664.

Epstein, E.(1993). The anomaly of silicon in plant biology. Proc. Natl. Acad. Sci. USA., 91: 11-17.

Hodson, M. J. and A. G. Sangster (1988). Silica deposition in the inflorescence bracts of wheat (Triticum aestivum). Scanning electron microscopy and light microscopy. Canada. J. Bot., 66: 281-287.

Jackson, M.L. (1967). Soil Chemical and Plant Analysis. Prentice Hall of India, New Delhi.

Jeschke, W.D and O. Wolf (1985). Na dependent net K translocation in leaves of Hordeum vulgar cv. 'California Mariout' and Hordeum distichon cv. 'Villa' under salt stress. J Plant Physiol, 121:211-223.

Kamenidou, S (2005). Silicon supplementation affects greenhouse produced cut flowers. M.Sc. Thesis, Graduate College of the Oklahoma State Univ. 92pp.

Kamenidou, S.; T.J. Cavins and S. Marek (2009). Evaluation of silicon as a nutritional supplement for greenhouse zinnia production. Scientia Horticulturae, 119: 297-301.

Kamenidou, S., T.J. Cavins and S. Marek (2010). Silicon supplements affect floricultural quality traits and elemental nutrient concentrations of greenhouse produced Gerbera. Scientia Horticulture, 123, 390-394. 
Kazemi, M.; M. Asadi and S. Aghdasi (2012). Postharvest life of cut Lisianthus flowers as affected by silicon, maleic acid and acetylsalicylic acid. Research J. Soil Biology, 4(1):15-20.

Long, J .; C. Hui-yan; D. Zhi-neng and L. Jian-fu (2018). The effect of silicon fertilizer on the growth of chives.2nd International Conference on Power and Energy Engineering (ICPEE 2018) IOP Publishing. IOP Conf. Series: Earth and Environmental Science, 192.

Lu, G. and Cao J.(2001). Effects of silicon on earliness and photosynthetic characteristics of melon. Acta Horticulture Sinica, 28, ( 5):421- 424.

Ma, J.F. and N. Yamaji (2006). Silicon uptake and accumulation in higher plants. Trends Plant Sci., 11: 392-397.

Ma, J.F. and E. Takahashi (2002). Soil, fertiliser, and Plant Silicon Research in Japan. Elsevier, Amsterdam.

Magouz, M. R. I. (2017). Physiological studies on some ornamental pot plants. M.Sc. Thesis, Fac. Agric. Kafr El-Sheikh Univ., Egypt.

McAvoy, R.J. and B. B. Bible (1996). Silica sprays reduce the evidence and severity of bract necrosis in poinsettia. Hort. Science, 31(7):1146-1149.

Moghaddam, S . M. M. and M. N. P. Dahkaei (2016). The effect of silicon on the growth traits and resistance of Zinnia (Zinnia elegans Jacq.) to powdery mildew disease. Journal of Ornamental Plants, 6( 3): 173-180.

Murphy, J. and J.D. Riely (1962). A modified single solution method for the determination of phosphate in natural water. Anal. Chem. Acta, 27: 3136.

Savvas, D.; G. Manos; A. Kotsiras and S. Soulaliotis (2002). Effects of silicon and nutrient induced salinity on yield, flower quality and nutrient uptake of gerbera grown in a closed hydroponic system. Journal of Applied Botany, 76(5/6):153-158.

Snedecor, G.W. and W.G. Cochran (1990). Statistical Methods. $7^{\text {th }}$ Ed. Iowa State Univ. Press. Ames., Iowa, USA., 593 pp.

Snyder, G.H.; V.V. Martichenkov and L.E. Datnoff (2007). Silicone. In:, (AV Barker and DJ Pilbean (eds), Handbook of Plant Nutrition). CRC Taylor and Francis, New York, USA, p: 551- 568.

Vendrame, W.A.; A. J. Palmateer.; A.Pinares; K.A. Moore and L.E. Datnoff (2010). Silicon fertilization affects growth of hybrid phalaenopsis orchid liners, HortTechnology (http:// Horttech. Ashs publications. org/content/20/3/603.short).

Wahba, H,E.; H.M. Motawe and A,Y, Ibrahim(2014). Chemical composition of essential oil, anthocyanins and fatty acids of Zinnia pauciflora. World Journal of Pharmaceutical Sciences, 2(12):1657-63. 
Xing, $X$ and $Z$. Lei (1998). Review of the studies on silicon nutrition of plants. J. Chinese Bulletin of Botany, (2): 2240.

Yadava, U.L. (1986). A rapid and nondestructive method to determine chlorophyll in intact leaves. Hort. Science, 21:1449-1450.

Zaky, A. A. (2013). Effect of pre- and postharvest treatments on flower longevity of cut rose cv.'Grand Prix. Egypt. J. Agric. Res., 91(3): 1009-1021.

Zhao, D.; Z. Hao; J. Tao and C. Han (2013). Silicon application enhances the mechanical strength of inflorescence stem in herbaceous peony (Paeonia lactifolia Pall.). Scientia Horticulturae, 151: 165-172.

Zhiming, X., R. I. Song., H. Shao. F. Song., H. Xu and Y. Lu (2015). Silicon improves maize photosynthesis in saline-alkaline soils. The Scientific World Journal. Article, ID 245072, 6 pages, 2015. doi: 10. 1155/ 2015/245072.

\section{تأثير مستويات وطرق اضافة السليكون على نمو وازهار الزينيا}

$$
\begin{aligned}
& \text { محمد السيا عبد الجيا } \\
& \text { قسم بحوث الحدائق النباتية ـ معهد بحوث البساتينـ مركز البحوث الزر اعيةـ الجيزة - }
\end{aligned}
$$

يعتبر السيليكون (Si) من العناصر الغذائية المفيدة التي تعمل على تحسين تحمل

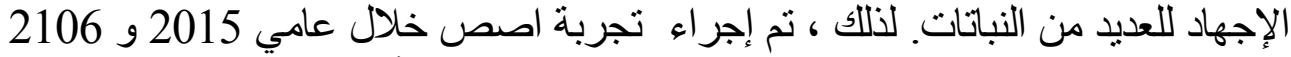

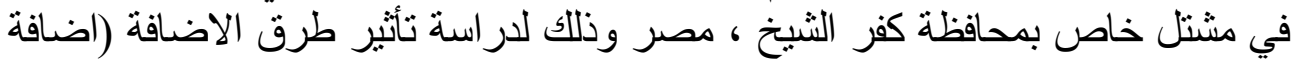

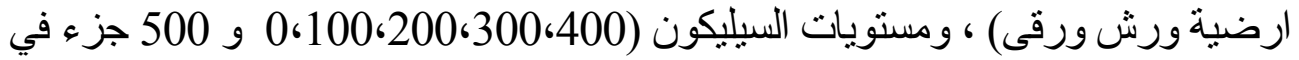

المليون) و التفاعل بينهما على النمو و الاز هار ، وكذلك التركيب الكيميائي لنباتات الزينيا.

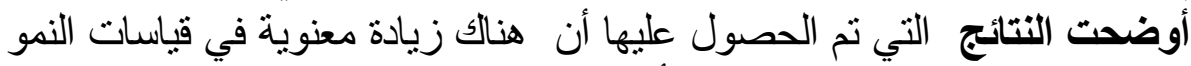

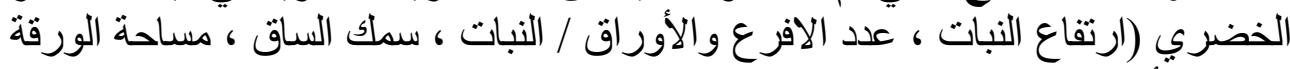

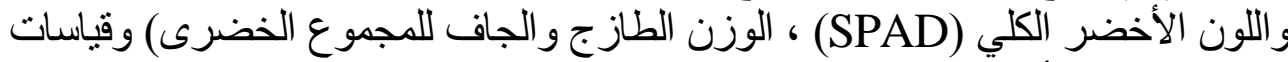

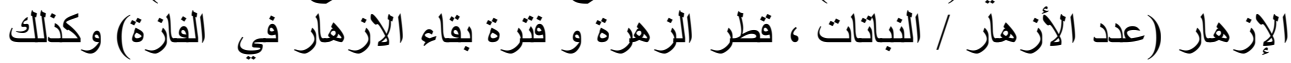

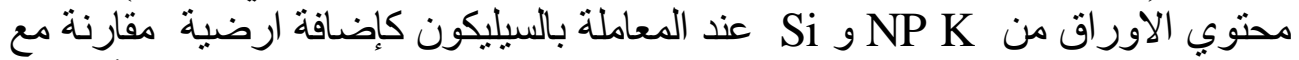
طريقة الرش الورقي ـ بالإضافة إلى ذللك ، وجد ان إن إضافة السيليكون بمعدل 500 أو 400

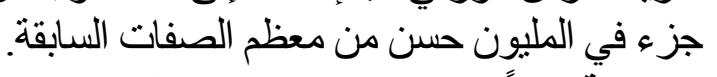

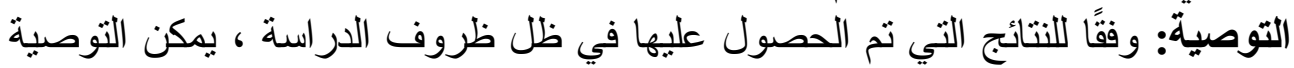

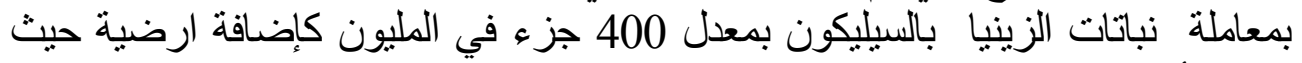

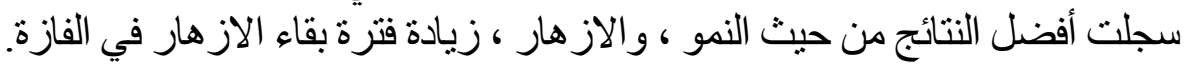

